\title{
In vivo monitoring of a cAMP-stimulated DNA-binding activity
}

\author{
Falk Weih, A. Francis Stewart, Michael Boshart, Doris Nitsch, and Günther Schütz \\ Institute of Cell and Tumor Biology, German Cancer Research Center, D-6900 Heidelberg, FRG
}

\begin{abstract}
The transcriptional activity of the tyrosine aminotransferase (TAT) gene is influenced by two major signal transduction pathways, by glucocorticoids and by glucagon acting via cAMP. We analyzed the effect of cAMP on protein-DNA interactions in vivo and on the transcription rate of the TAT gene. We demonstrate that a cAMP-responsive element (CRE) is located in a tissue-specific DNase I-hypersensitive region, $3.6 \mathrm{~kb}$ upstream of the start site of transcription. By using the genomic footprinting technique, we show that this sequence is occupied by protein in uninduced cells and that the in vivo footprint is transiently increased upon cAMP induction. Protein binding at the TAT-CRE correlates with the rate of transcription of the TAT gene. Cycloheximide treatment reveals that the genomic footprint is subject to rapid turnover; however, subsequent cAMP induction in the continued presence of cycloheximide restores the footprint partially. We conclude that as a part of the signal transduction pathway, a cAMP-dependent, post-translational modification increases the DNA-binding activity of a protein to the TAT-CRE and thereby stimulates the transcription rate of the TAT gene.
\end{abstract}

[Key Words: In vivo footprinting; signal transduction; transcriptional regulation; cAMP; CRE-binding protein] Received September 14, 1989; revised version accepted April 23, 1990.

Cells react to their environment by transducing external signals into intracellular responses. Two major distinct mechanisms of signal transduction have been elucidated. First, binding of the signaling molecule to intracellular receptors directly, as exemplified by steroid hormones, influences gene activity by inducing DNA binding of the receptor. As a consequence of binding, chromatin structure is altered and the transcription rate of the corresponding gene is either increased or repressed (for reviews, see Yamamoto 1985; Evans 1988; Green and Chambon 1988; Beato 1989). By use of the genomic footprinting technique, it has been demonstrated that in vivo binding of steroid receptors to their target sites is dependent on the presence of the hormone (Becker et al. 1986; Philipsen et al. 1988; Wijnholds et al. 1988).

Second, many polypeptide hormones and growth factors bind to specific cell-surface receptors and lead to altered intracellular levels of second messengers such as inositol-3-phosphate (IP-3), diacylglycerol (DAG), $\mathrm{Ca}^{2+}$, and $C A M P$. These second messengers activate specific protein kinases which, in some cases, influence gene activity by as-yet-undetermined mechanisms (for reviews, see Hokin 1985; Edelman et al. 1987; Gilman 1987). For instance, the transcriptional stimulation of the protooncogene c-fos by epidermal growth factor (EGF) requires DNA sequences located between -317 and -290 of the c-fos 5'-flanking region, including the serum response element (SRE; Treisman 1985). In contrast to the inducible binding of steroid hormone receptors, genomic footprinting has shown that the SRE is bound by pro- teins to the same extent before, during, and after induction of the c-fos gene (Herrera et al. 1989).

During the last several years, numerous genes responding to elevated levels of cAMP have been analyzed. A cis-acting DNA sequence referred to as a cAMP-responsive element (CRE) has been characterized in many of these genes (Comb et al. 1986; Montminy et al. 1986; Delegeane et al. 1987; Silver et al. 1987; Tsukada et al. 1987; Bokar et al. 1988; Quinn et al. 1988; Dean et al. 1989; Fisch et al. 1989). cAMP acts by binding to the regulatory subunit of the cAMP-dependent protein kinase (PK-A), thereby causing the regulatory and catalytic subunits of the holoenzyme to dissociate (for review, see Edelman et al. 1987). This results in transcriptional activation of certain genes, possibly via direct phosphorylation of transcriptional regulatory proteins (Yamamoto et al. 1988; Bagchi et al. 1989; Gonzalez and Montminy $1989 \mid$.

We are analyzing the transcriptional regulation of the tyrosine aminotransferase (TAT) gene, which is expressed exclusively in parenchymal cells of the liver (for review, see Hargrove and Granner 1985). This gene is transcriptionally responsive to members of both classes of signal transduction. The sequence through which the glucocorticoid receptor acts [glucocorticoid responsive element (GRE)] to stimulate the TAT gene was initially identified by an inducible DNase I hypersensitive (HS) site (Becker et al. 1984) and subsequently characterized in detail by gene transfer experiments (Jantzen et al. 1987). Upon administration of glucocorticoids, a local 
chromatin change results, as revealed by HS site mapping and genomic footprinting (Becker et al. 1986; Jantzen et al. 1987). A functional GRE is 15 bp long and acts as an inducible transcriptional enhancer when multimerized (Strähle et al. 1988). Apart from glucocorticoid induction, the activity of the TAT gene is also regulated on the transcriptional level by glucagon via its intracellular mediator, cAMP (Hashimoto et al. 1984; Schmid et al. 1987).

Here, we report that after cAMP stimulation, an in vivo footprint on a sequence with close homology to known CREs alters in parallel to the transcription rate of the TAT gene. These alterations are also apparent as changes in the DNA-binding activity of a factor in vitro. We show that CAMP-mediated signal transduction to the TAT gene involves post-translational modifications, which affect a factor's DNA-binding activity.

\section{Results}

A DNase I HS region centered around $-3.6 \mathrm{~kb}$ is correlated with active TAT gene transcription

The initial indication that a regulatory element of the TAT gene is located farther upstream than the GRE at $-2.5 \mathrm{~kb}$ was obtained by DNase I HS site mapping. In TAT-expressing FTO-2B hepatoma cells (Killary and Fournier 1984), a strong HS site around $-3.6 \mathrm{~kb}$ can be detected (Fig. 1A; HS site -3.6). This HS is dependent neither on dexamethasone nor on cAMP induction. In contrast, the HS site at $-2.5 \mathrm{~kb}$ is not present in the absence of glucocorticoids, as described earlier (Becker et al. 1984; Jantzen et al. 1987). The TAT nonexpressing fibrosarcoma cell line XC (Svoboda 1960) does not show these HS sites, whether they have been induced or not. Precise mapping of HS site -3.6 shows that intense DNase I cleavages are found in the region between -3500 and -3800 (Fig. 1 and data not shown). A detailed analysis of the chromatin structure of the TAT gene will be published elsewhere (D. Nitsch et al., in prep.).

\section{Genomic footprinting reveals specific protein-DNA interactions at a CRE-related sequence}

To analyze the DNase I HS region at $-3.6 \mathrm{~kb}$ in greater detail, we applied the genomic footprinting technique (Church and Gilbert 1984) to FTO-2B, and as a control, to XC cells. Treatment of intact cells with dimethyl sulfate (DMS) results in methylation of guanosines at the N7 position in the major groove, rendering them susceptible to cleavage with piperidine (Maxam and Gilbert 1980). Specific guanosine residues closely associated with a protein will be protected from methylation by DMS. Enhanced reactivity of certain guanosines may result when protein-DNA interactions generate a local hydrophobic environment close to a target guanine (Gilbert et al. 1976). In addition, protein-induced local alter-
Figure 1. The DNase I HS site $3.6 \mathrm{~kb}$ upstream is present only in TAT-expressing cells. (A) Nuclei were isolated from FTO$2 B$ cells and uninduced XC cells (XC). FTO-2B cells were either incubated in serumfree medium (FTO), induced for $1 \mathrm{hr}$ with 1 $\mu \mathrm{M}$ dexamethasone (FTO/DEX), or incubated for $1 \mathrm{hr}$ in the presence of $0.5 \mathrm{mM}$ cAMP (FTO/cAMP). Preparations of isolated nuclei were digested with increasing amounts of DNase I for $10 \mathrm{~min}$ on ice. Numbers above each lane indicate the DNase I concentration used (in $\mathrm{U} / \mathrm{ml}$ ) reaction volume. DNA was purified and, after digestion with BamHI, separated on a $1 \%$ agarose gel $(20 \mu \mathrm{g} /$ lane), blotted, and hybridized. The probe was a T3RNA polymerase transcript from subclone pEB670 (-1974 to -1301$)$ of the TAT gene. (M) End-labeled $\lambda$ marker DNA whose size (in $\mathrm{kb})$ is indicated at left. The HS sites at -3.6 and -2.5 are indicated by arrows. $(B)$ The $5^{\prime}$ flanking region of the TAT gene, including DNase I HS sites up to $-6 \mathrm{~kb}$ is depicted. The glucocorticoid-inducible HS site at -2.5 is labeled with GRE. The constitutive HS site at -3.6 is characteristic for basal level and cAMP-induced transcription.

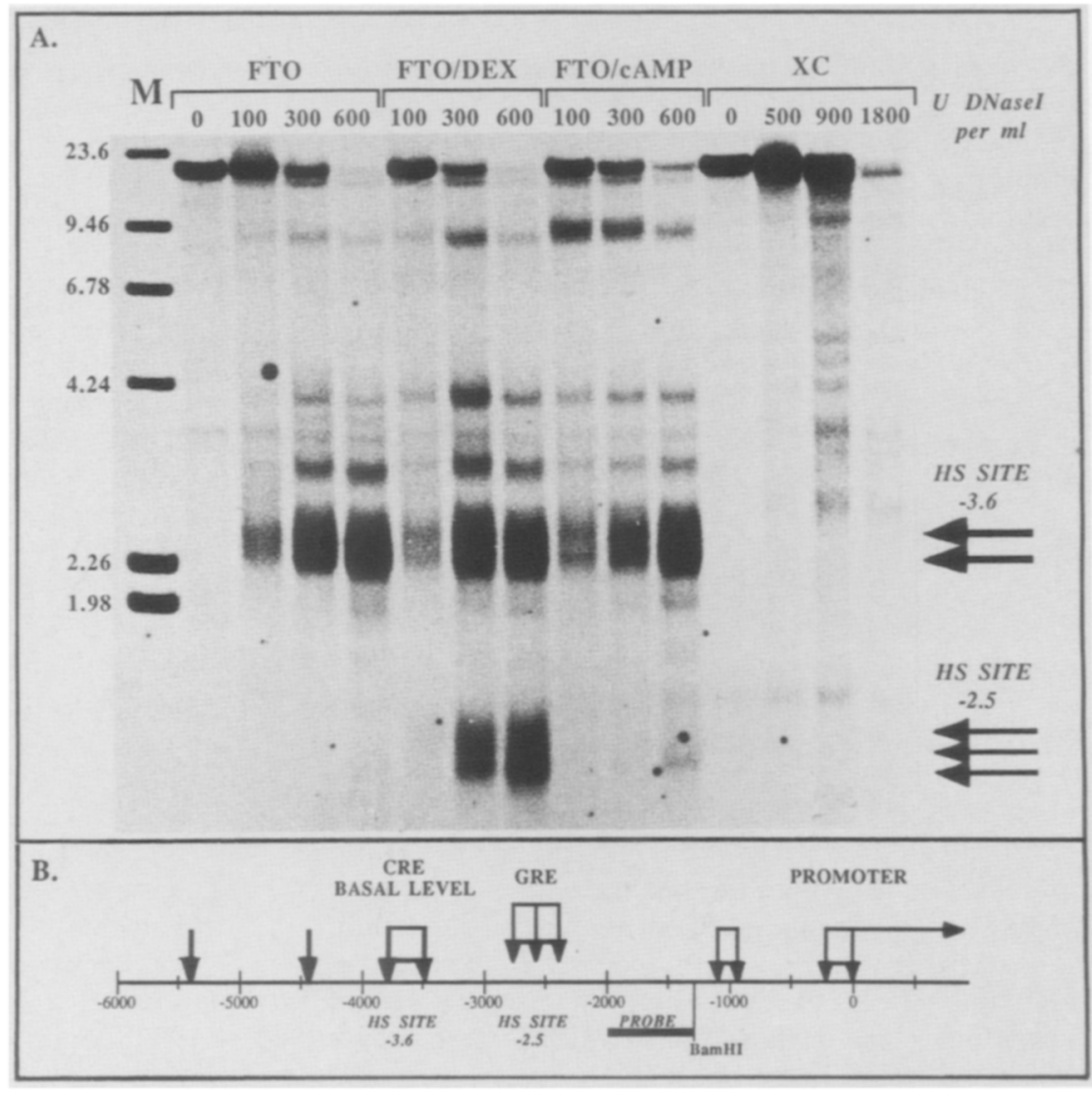


ations in DNA conformation may alter the reactivity of guanine residues against DMS (Johnsrud 1978).

Whereas the reaction pattern obtained from XC cells is essentially indistinguishable from partially methylated protein-free DNA (not shown), FTO-2B cells demonstrate a pattern of protections and enhancements, indicating the binding of protein. As Figure 2 shows, the 5 '-boundary of this in vivo footprint is marked by a hyperreactive guanosine at -3651 on the lower strand (lower, FTO-2B) and by a very strong enhancement at G -3649 on the upper strand (upper, FTO-2B). All of the guanosine residues on either strand down to $G-3643$, which again shows enhanced reactivity, are at least par-

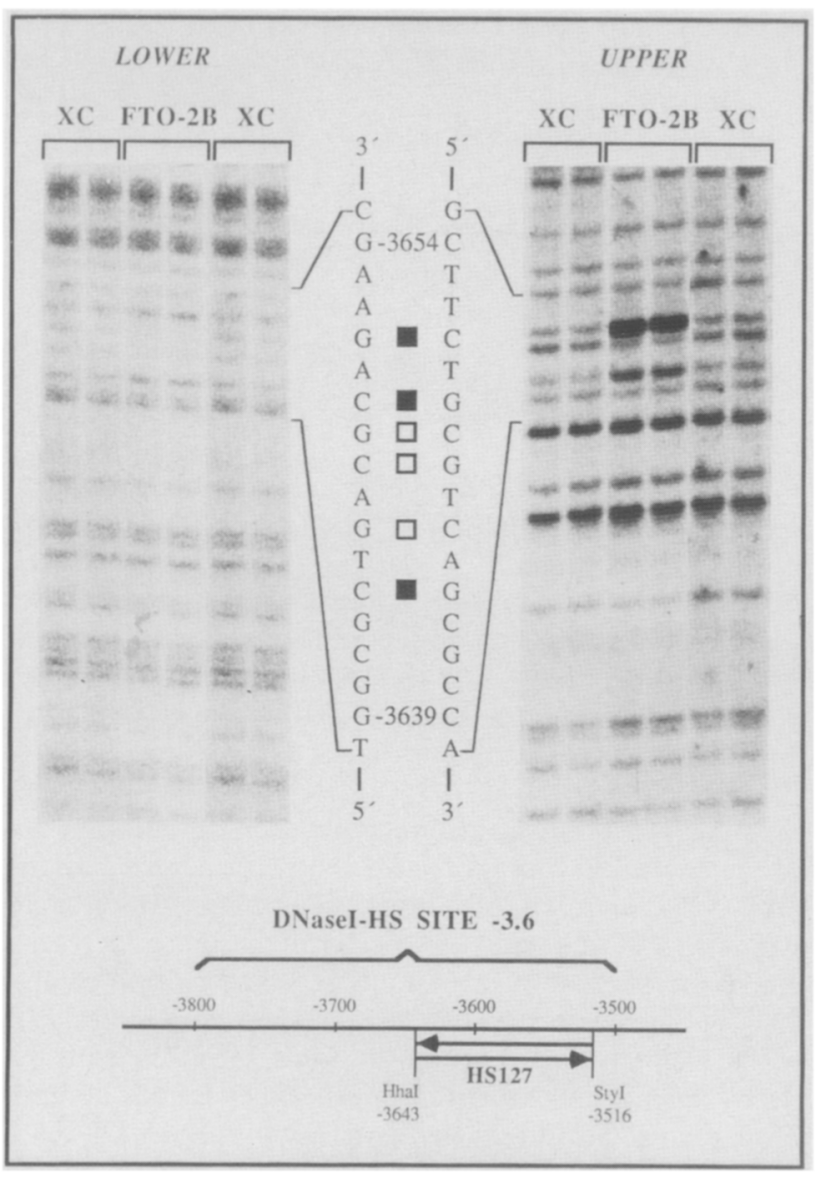

Figure 2. In vivo footprinting experiments reveal proteinDNA interactions within HS site -3.6 . XC and FTO-2B cells were incubated with DMS for $5 \mathrm{~min}$ at room temperature. After purification, DNA was digested with StyI and the backbone was cleaved at positions of methylated guanosines with piperidine. Thirty micrograms of genomic DNA per lane was electrophoresed on a $6 \%$ denaturing polyacrylamide gel, electroblotted onto GeneScreen, baked at $80^{\circ} \mathrm{C}$, and covalently cross-linked by UV irradiation. Membranes were then hybridized with a singlestranded DNA probe of high specific activity. Guanosine residues that show an altered reactivity in FTO-2B cells, as compared to XC cells: enhancements ( $\square$ ); protections ( $\square$ ). (Bottom) The location of the probe and the extent of the DNase I HS region at -3.6 . Numbers indicate the position of base pairs relative to the start site of transcription. tially protected from DMS attack. The differences in DMS reactivity of FTO-2B cells compared to XC cells are summarized in the middle of Figure 2. The sequence indicated by the genomic footprint is closely related to CREs, the binding site of the activating transcription factor (ATF) in several adenoviral genes, and the recognition site of the Fos-Jun complex AP-1 (for review, see Jones et al. 1988).

\section{The TAT-CRE confers CAMP responsiveness to a heterologous promoter}

To test directly whether this sequence contacted by protein in expressing cells fulfills the criteria of a CRE, we concatemerized a DNA fragment $(-3659$ to -3634$)$, including the sequence covered by the in vivo footprint, and inserted it upstream of the herpes simplex virusthymidine kinase (HSV-TK) promoter. As a control, we used a DNA fragment that differs from the original sequence only by a triple-point mutation. We chose to mutate the three guanosine residues that are protected in the genomic footprint (see Fig. 2). The sequence of wild-type and mutated DNA fragments is presented in Figure 3B. The bacterial chloramphenicol acetyltransferase (CAT) gene was used as reporter, and expression was monitored by analysis of CAT activity. Induction of transfected FTO-2B cells was carried out with forskolin, a drug that activates adenylate cyclase and thereby raises intracellular cAMP levels (Seamon et al. 1981). As shown in Figure 3A, the concatemerized TAT sequence is capable of conferring cAMP responsiveness to a heterologous promoter. CAT activity is stimulated 24-fold after only $4 \mathrm{hr}$ of forskolin induction, indicating a direct response of the reporter plasmid to elevated intracellular cAMP levels. The basal level expression of the mutated version is close to background and does not show significant stimulation after forskolin induction (less than threefold). Therefore, this sequence element henceforth is referred to as TAT-CRE. Interestingly, the TATCRE also increases basal level expression of the TK promoter by at least 15 -fold. Inverting the orientation of the concatemerized fragments gives similar results (not shown). The effect on basal level transcription mediated by the TAT-CRE correlates well with the observation that this sequence is occupied in vivo by protein already in the uninduced state (see Fig. 2).

\section{Mutations at the TAT-CRE affect both basal and cAMP-stimulated activities of the TAT promoter}

To demonstrate the functionality of the TAT-CRE at its natural position, we stably integrated TAT-CAT constructs into FTO-2B cells and examined the effects of CRE mutations on TAT-CAT RNA synthesis by ribonuclease protection experiments. As shown in Figure $4 \mathrm{~A}$, a construct including the TAT-CRE $(-3675)$ responds to forskolin treatment, whereas a 5 '-deletion to remove the TAT-CRE $(-3628)$ or the introduction of the same three point mutations at the TAT-CRE, as depicted in Figure 3B, into the -3675-bp TAT-CAT construct $(-3675 / \mathrm{M} 3)$, results in a loss of cAMP responsive- 
Weih et al.

Figure 3. The TAT-CRE confers cAMP responsiveness. $(A)$ Oligonucleotides (six direct repeats; sequence in $B$ ) harboring either the wild-type (wt) or the mutated (mut) TATCRE were cloned in front of the HSV-TK promoter driving the bacterial CAT gene. FTO-2B cells were transfected by electroporation, split onto separate dishes, and either mock-induced with $0.1 \%$ ethanol or induced with $10 \mu \mathrm{M}$ forskolin. Extracts were prepared $4 \mathrm{hr}$ after DNA transfer, and CAT assays were performed. CAT activities were corrected for a cotransfected luciferase standard driven by the Rous sarcoma virus long terminal repeat (RSV-LTR), and basal (uninduced) activity of the mutated construct was arbitrarily defined as $1 .(B)$ Sequence of oligonucleotides used for construction of reporter plasmids and gel retardation experiments. Numbers refer to the position of bases relative to the start site of transcription. Three guanosine residues, which are protected from DMS attack in vivo, were changed in the mutated version of the

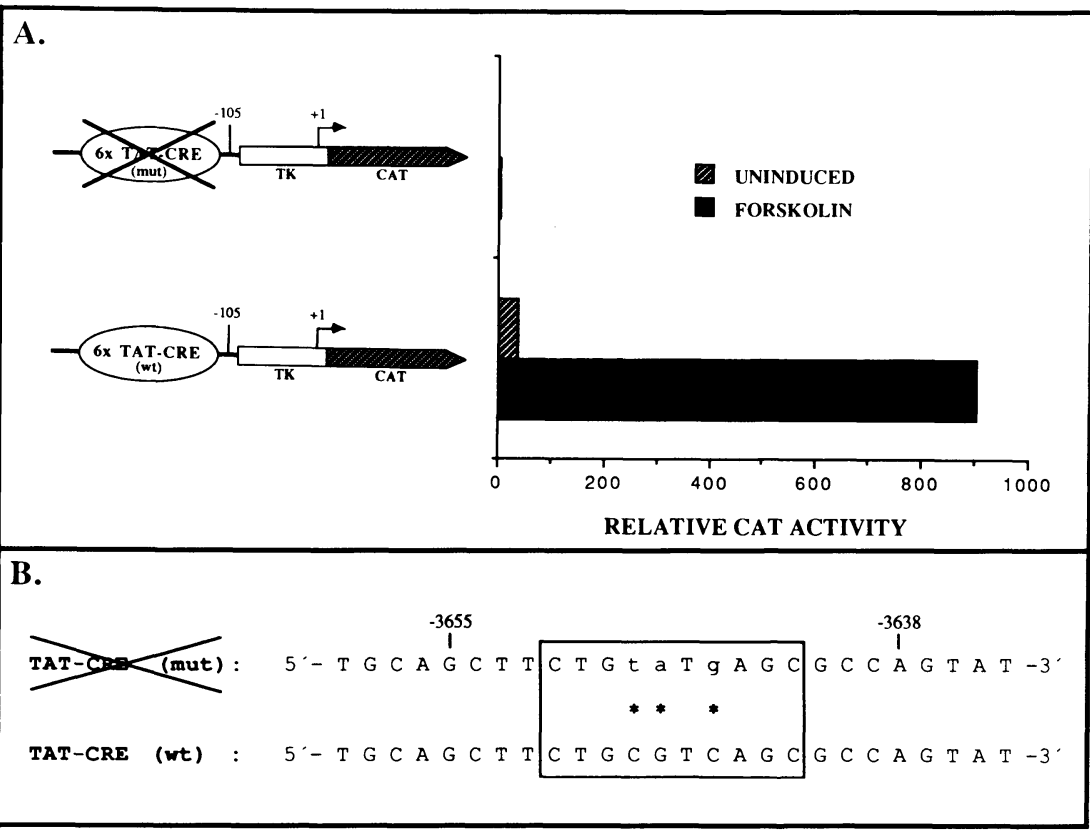
TAT-CRE (indicated by lowercase letters and asterisks).

ness. Interestingly these mutations also reduce basal level expression $>20$-fold (quantitated by scintillation counting). In the lower part of Figure 4A, the signal from the endogenous TAT gene $(\mathrm{E})$ is shown as a control. Examination of 5 ' sequences up to -3923 bp did not alter cAMP responsiveness compared to the -3675 bp TATCAT construct (data not shown). From the ribonuclease protection experiments, we conclude that the TATCRE is essential for high basal level activity of the TAT promoter and, taken together with the results of Figure 3 , at least partly responsible for mediating the cAMP stimulation of TAT gene transcriptional activity. Because we do not observe the same foldness of induction of the introduced gene as the endogenous one, it may be that a component missing from our experiments contributes to the cAMP response of the TAT gene.

The in vivo footprint at the TAT-CRE and the transcription rate of the TAT gene transiently respond to $c A M P$

Because the genomic footprint covers a DNA sequence involved in cAMP responsiveness, we analyzed the effect of forskolin on the protein-DNA interactions in vivo. FTO-2B cells were stimulated with $10 \mu \mathrm{M}$ forskolin. After the times shown, the cells were reacted with DMS and, subsequently, genomic DNA was purified and processed for genomic sequencing. Striking effects were found in FTO-2B cells after 30 and 50 min of cAMP induction (Fig. 5A). Protein is already bound at the TAT-CRE in the uninduced state (lane 2), and footprint strength is increased approximately threefold upon forskolin administration (lanes 3 and 4). Interestingly, the intensification of the footprint is transient and decreases after prolonged incubation of FTO-2B cells with forskolin. The demonstration of a genomic footprint at the TAT-CRE in uninduced FTO-2B cells (see Figs. 2 and 5) is consistent with a DNase I HS site at $-3.6 \mathrm{~kb}$ in the uninduced state.

To quantify the recorded effects, densitometric scannings from the autoradiograph were made. The degree of protein-DNA interaction was correlated to hyperreactivity of G-3649 on the upper strand and compared under noninducing and inducing conditions. Basal level of footprinting activity at the TAT-CRE in uninduced FTO-2B cells was arbitrarily defined as one relative footprint unit. The result is summarized in the lower part of Figure 5A.

To correlate transcriptional activation of the promoter more precisely with increased footprint activity at the TAT-CRE upon cAMP induction, nuclear run-on analysis with FTO-2B cells was performed. Figure 5B shows the result of this experiment. The transcription rate of the TAT gene in FTO-2B cells is increased fivefold, it peaks $\sim 60 \mathrm{~min}$ after forskolin administration, and declines again after $90 \mathrm{~min}$. These experiments demonstrate a correlation between enhanced protein-DNA interactions at the TAT-CRE and the increased rate of TAT gene transcription in cAMP-induced FTO-2B cells. This result is consistent with the observation of Hashimoto et al. (1984), who found that transcriptional stimulation of the TAT gene in rat liver by cAMP is also transient.

The genomic footprint at the TAT-CRE is abolished by cycloheximide but can be restored partially by cAMP

To address the question whether the intensification of the footprint at the TAT-CRE is due to a cAMP-mediated post-translational event, protein synthesis was blocked with cycloheximide (CHX). The concentration 


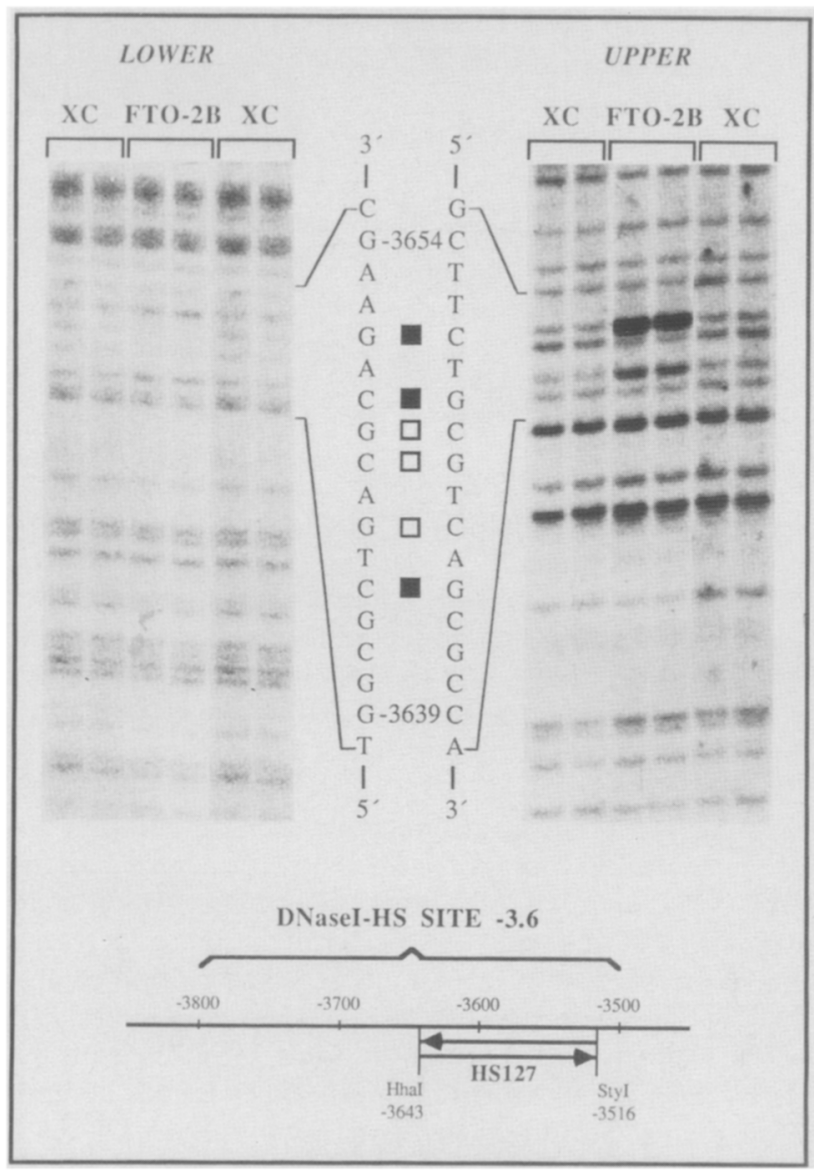

Figure 4. The TAT-CRE is functional in its natural context. (A) Different TAT 5 '-flanking sequences were cloned in front of the bacterial CAT gene and stably integrated into FTO-2B cells. RNA was prepared from untransfected and uninduced control cells $(C)$ and stably transfected pools that were treated with $0.1 \%$ ethanol (-) or induced with $10 \mu \mathrm{M}$ forskolin for $1 \mathrm{hr}(1), 2$ $\mathrm{hr}(2)$, and $4 \mathrm{hr}(4)$. -3675 and -3628 denote the $5^{\prime}$-deletion end point of TAT-CAT constructs (in base pairs), - 3675/M3 denotes a construct where the TAT-CRE has been mutated by the same 3-bp exchanges as shown in Figure 3B. Total RNA 140 $\mu \mathrm{g}$ ) was hybridized to 10 fmoles of a uniformly labeled antisense SP6 transcript and digested with RNase A and T1. Protected fragments were separated on a $7.5 \%$ sequencing gel. The gel shown for the TAT-CRE mutants $(-3628$ and $-3675 / \mathrm{M} 3)$ was exposed for a longer time to compensate for the reduced signals. The endogenous TAT gene (E) serves as a control and displays microheterogeneity at its start site. (CS) Correctly initiated transcripts; $(\mathrm{RT})$ readthrough transcripts; $(\mathrm{P})$ undigested probe; $(M)$ end-labeled marker; fragment sizes (in bp) are indicated at left. $(B)$ Expected fragments protected from ribonuclease digestion are shown with their calculated size.

of CHX used $(50 \mu \mathrm{g} / \mathrm{ml})$ was more than sufficient to block protein synthesis completely, as assayed by incorporation of $\left[{ }^{35}\right.$ S]methionine (not shown). As a first control, uninduced FTO-2B cells were treated for increasing length of time with CHX. Surprisingly, we found that the in vivo footprint at the CRE becomes weaker and completely disappears after 3-4 hr (Fig. 6A, lanes 5 and 6). This finding indicates that ongoing protein synthesis is required to maintain basal-level binding activity to the TAT-CRE. To quantify the half-life of this footprint activity, the autoradiograph was scanned and evaluated as outlined above. The result is shown in the lower part of Figure 6A. After 60-75 min of incubation with CHX, $50 \%$ of the DNA binding activity to the TAT-CRE is abolished.

Subsequently, we treated FTO-2B cells with CHX for $3 \mathrm{hr}$ to clear the TAT-CRE of binding and then induced with $10 \mu \mathrm{M}$ forskolin. As shown in Figure 6B, the in vivo footprint can be restored, at least partially. This induction is also transient, and the kinetics are very similar to those observed above with cells that have not been treated with CHX (see Fig. 5). The reduced intensity of the footprint stimulated by cAMP in the presence of CHX may be due to a decreased amount of the relevant binding activity in the cell. If forskolin is added to the cells in parallel with CHX, the effect is similar to the result shown in Figure 5A, although the footprint activity is slightly reduced (not shown).

To correlate the result shown in Figure 6A with TAT gene expression, we performed Northern analysis of uninduced and forskolin-induced hepatoma cells in the presence or absence of CHX. Figure 6C shows that CHX treatment significantly reduces TAT mRNA in uninduced and forskolin-induced cells. As a control we probed for GAPDH mRNA, which is not affected by either CHX or forskolin treatment.

These results indicate that (1) the occupancy of the TAT-CRE in the uninduced state is subject to turnover, and (2) cAMP, by a post-translational mechanism, increases footprinting activity on the TAT-CRE.

In vitro binding analyses of protein-DNA interactions at the TAT-CRE confirm in vivo observations

To analyze the protein interaction with the TAT-CRE in greater detail, we attempted to complement the above results by in vitro binding assays. The sequences of the TAT gene-specific oligonucleotides used in gel retardation assays (Fried and Crothers 1981; Garner and Revzin 1981) are shown in Figure 3B. Figure 7A shows that two specific complexes-A and B-form with the TATCRE but not with the mutated sequence. In a competition experiment only the wild-type fragment competes for complexes A and $\mathrm{B}$; no competition is observed with the mutated binding site, even at a 400 -fold molar excess (Fig. 7B).

To search for possible differences in the way A and B recognize DNA, methylation interference analysis (Siebenlist and Gilbert 1980) with both complexes was performed. As shown in Figure 7G, methylation of G $-3649, \mathrm{G}-3647, \mathrm{~A}-3644$, and $\mathrm{G}-3643$ on the upper strand and G - 3648, G - 3645, and G -3642 on the lower strand strongly interferes with formation of complex B. The methylation interference pattern correlates with the methylation protection pattern of the genomic footprint (see lower part of Fig. 7G). The methylation interference pattern of complex A is identical, although generally less pronounced (not shown). It appears that the proteins involved in the formation of both com- 
Figure 5. The in vivo footprint at the TAT$\mathrm{CRE}$ and the TAT gene transcription rate transiently respond to cAMP. (A) FTO-2B cells were induced for the indicated periods with $10 \mu \mathrm{M}$ forskolin. After in vivo methylation, purified DNA was further processed as detailed in Fig. 2. (F) Forskolin induction. Symbols and numbering are as detailed in Fig. 2. The autoradiograph shown at top was quantified by densitometric scannings on a Hirschmann Elscript 400 scanner. Footprint activity in uninduced FTO-2B cells was correlated to hyperreactivity of $\mathrm{G}-3649$ and arbitrarily defined as 1 relative footprint unit. $(B)$ Nuclear run-on analysis of nuclei prepared from FTO-2B cells induced for the indicated periods with $10 \mu \mathrm{M}$ forskolin. Quantification was done by Cerenkov counting. The values (in $\mathrm{cpm}$ ) for the relative transcription rate of the TAT gene are shown in the diagram. (GAPDH) glyceraldehyde-3-phosphate-dehydrogenase gene; (B. scribe) Bluescribe $\mathrm{Ml3}^{-}$ plasmid.

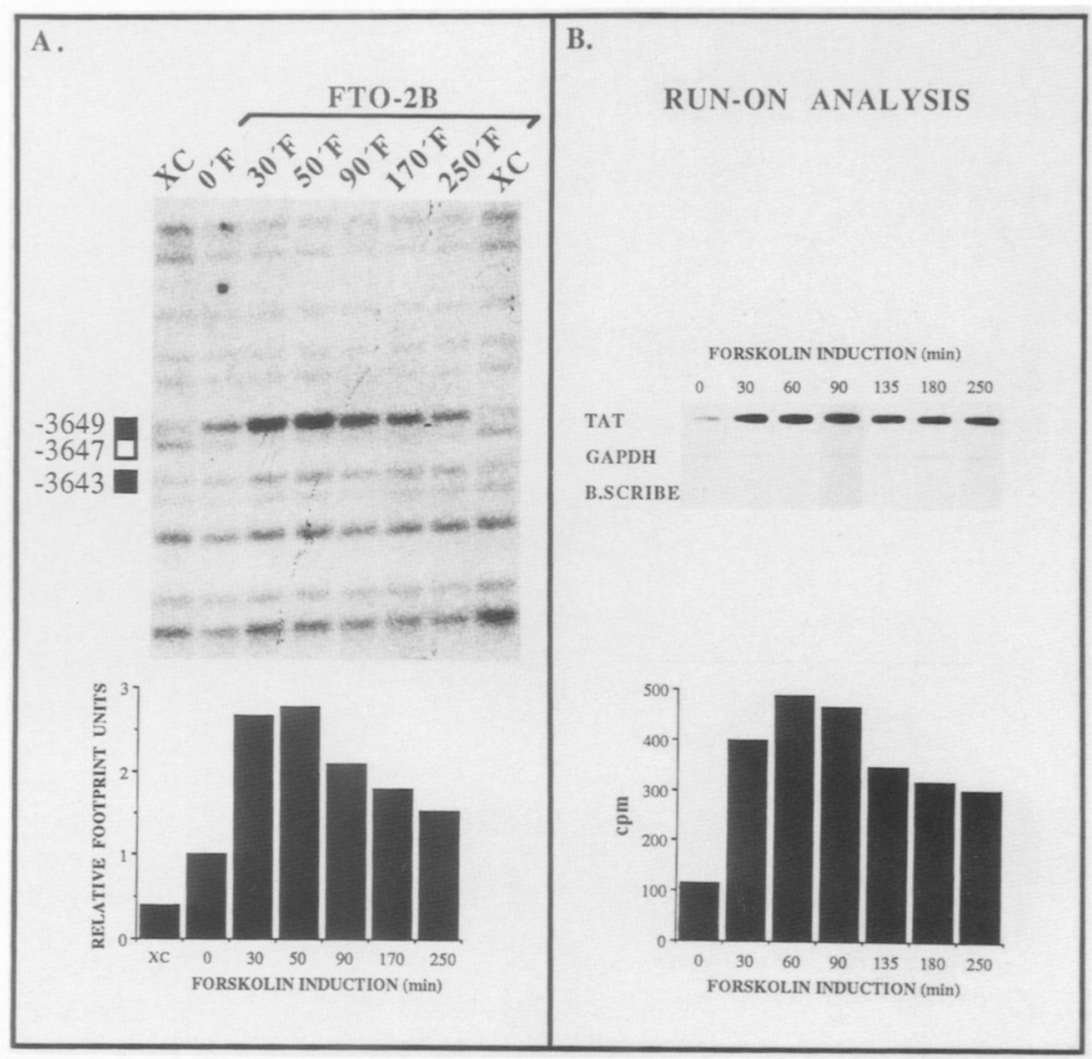

plexes contact the same bases and bind with comparable affinities to the TAT-CRE.

To establish a correlation of the in vivo findings with the situation in vitro, we looked for changes of proteinDNA interactions in gel retardation experiments after treatment of hepatoma cells with either cAMP or CHX. Therefore, we prepared nuclear extracts from FTO-2B cells that were induced for $30 \mathrm{~min}$ with $10 \mu \mathrm{M}$ forskolin. Because we realized that the ratio between complexes $A$ and $B$ varied in different extract preparations, the untreated control extracts were prepared in parallel; Figure $7 \mathrm{C}$ shows the result of this experiment. In extracts prepared from forskolin-induced cells, the formation of complex B is increased 3.5-fold (quantified by densitometric scannings), whereas formation of complex $A$ is not influenced at all. The increase in DNA-binding activity in this assay correlates well with the results obtained from the genomic footprinting analysis.

Similarly, nuclear extracts from cells treated with $\mathrm{CHX}(50 \mu \mathrm{g} / \mathrm{ml})$, or untreated, were prepared. Again, only complex B was affected by $\mathrm{CHX}$ treatment being almost completely abolished, whereas complex A was not influenced (Fig. 7C). From these results, we concluded that the effects observable by in vivo footprinting are mediated by alterations in the DNA-binding activity of a protein that forms complex $\mathrm{B}$ in a gel retardation assay.

Because the TAT-CRE is closely related to the somatostatin CRE (Montminy et al. 1986), we compared both sequences directly in gel retardation assays. As shown in Figure 7D, three complexes (B, C, and D) form with the labeled somatostatin CRE, only one of which comigrates with complex B of the TAT-CRE. When the somatostatin CRE is used as a competitor to the labeled TAT-CRE, only complex B is competed, whereas complex A remains unchanged (see Fig. 7E). This experiment suggests that the protein forming complex B with the TAT-CRE also binds to the somatostatin CRE. However, the reverse experiment does not deliver the complementary result. When the somatostatin CRE is used as labeled fragment, the TAT-CRE does not compete significantly for any of the three complexes we observe (data not shown). Furthermore, when the somatostatin CRE is used with the same nuclear extracts as shown in Figure $7 \mathrm{C}$ in a gel retardation assay, neither a forskolindependent increase nor a $\mathrm{CHX}$-caused decrease in complex formation is observed with any of the three complexes, B, C, or D (Fig. 7F). Taken together, these results indicate that the TAT-CRE is recognized differently than the somatostatin CRE.

\section{Discussion}

We analyzed protein-DNA interactions of the TAT gene in intact rat hepatoma cells and identified in vivo a footprint over a sequence element that bears homology to known CREs. That this element mediates cAMP responsiveness and contributes to the basal level of TAT gene transcription was demonstrated by gene transfer experiments. We show elsewhere (Boshart et al. 1990) that this element acts synergistically with a hepatocyte- 


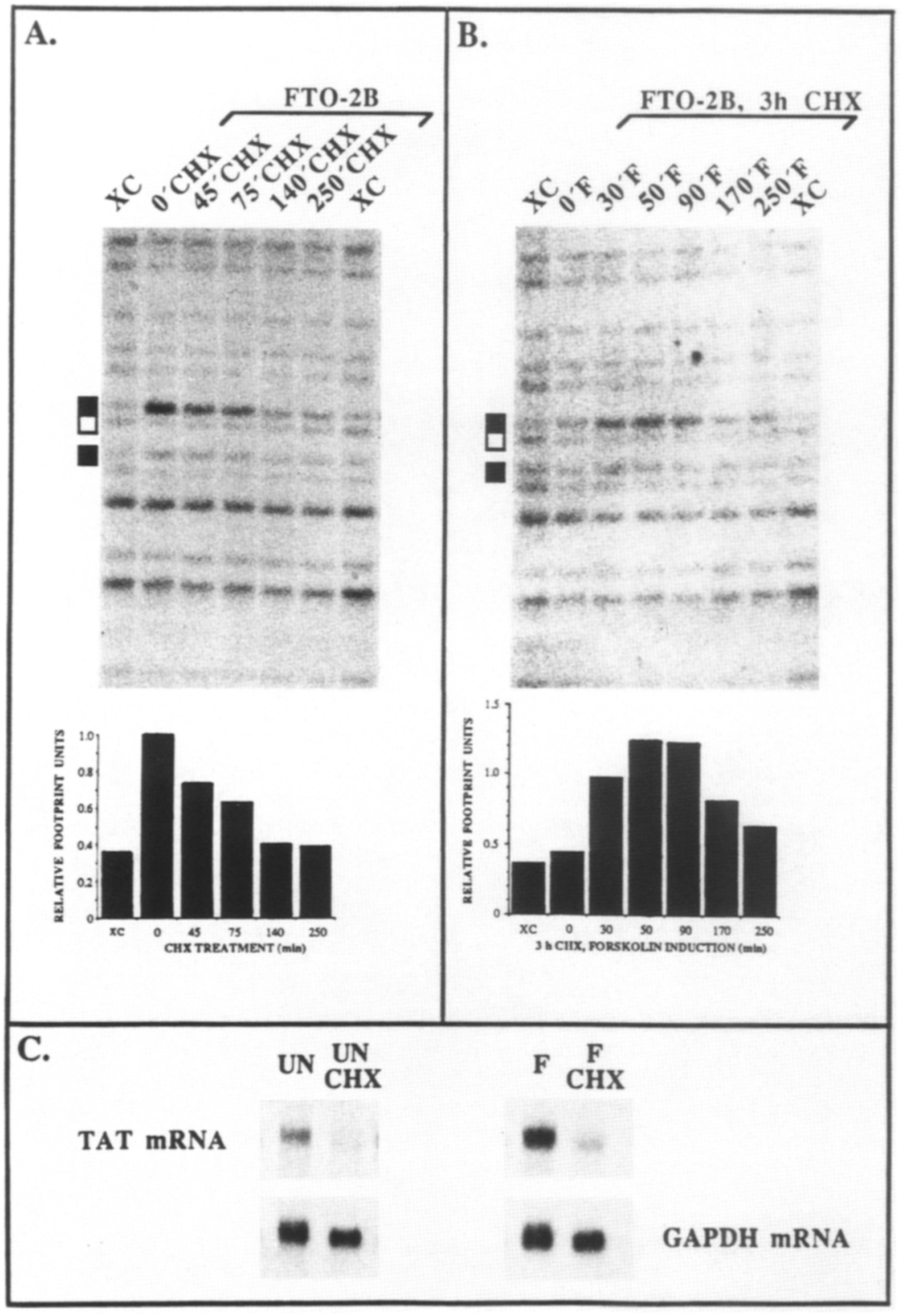

Figure 6. The in vivo footprint at the TATCRE is sensitive to CHX but can be restored partially by cAMP. (A) FTO-2B cells were incubated for the indicated periods with 50 $\mu \mathrm{g} / \mathrm{ml} \mathrm{CHX}$, and DNA was then methylated in vivo and processed further as outlined in Fig. 2. (B) FTO-2B cells were incubated for 3 hr with $50 \mu \mathrm{g} / \mathrm{ml} \mathrm{CHX}$ and subsequently induced for the indicated periods with $10 \mu \mathrm{M}$ forskolin in the continuing presence of $\mathrm{CHX}$. Quantitation of footprint activity, symbols, and abbreviations are as detailed in Figs. 2 and 5. (C) CHX affects TAT mRNA levels. Cells were either not induced or induced with $10 \mu \mathrm{M}$ forskolin in the presence or absence of CHX $(50 \mu \mathrm{g} / \mathrm{ml})$ for $6 \mathrm{hr}$. The signal for GAPDH mRNA on the same Northern blot is shown as a control. specific constitutive element located in close proximity to the TAT-CRE. Because the maximal transcriptional response of the TAT gene to cAMP is transient, we looked for and found transient responsiveness of the genomic footprint. Intensity of the footprint and the transcriptional response showed similar kinetics following cAMP induction, strongly suggesting that the increased rate of transcription is a consequence of increased formation of this protein-DNA complex. The inducible protein-DNA interaction can also be observed by in vitro DNA binding assays with the TAT-CRE.

The genomic footprint at the TAT-CRE is influenced in two ways. First, it is transiently intensified by cAMP, even in the presence of $\mathrm{CHX}$, indicating that a posttranslational event is involved in the increased footprint strength. Second, the footprint is abolished by $\mathrm{CHX}$ treatment, suggesting that ongoing protein synthesis is required for its maintenance and that the DNA-binding activity of this protein is subject to turnover. This could involve synthesis and degradation of the protein itself or, more likely, mechanisms that cycle its DNA-binding activity. From these observations, we conclude that the DNA-binding activity of this protein can be influenced by interference with protein synthesis and by a posttranslational modification.

A model for this post-translational modification involves protein phosphorylation by the catalytic subunit of PK-A, which may result in a conformational change of the TAT-CRE-binding protein. Although we have not ascertained whether the TAT-CRE-binding factor is a phosphoprotein, it has been demonstrated that the transcriptional stimulation of the TAT gene by cAMP is me- 


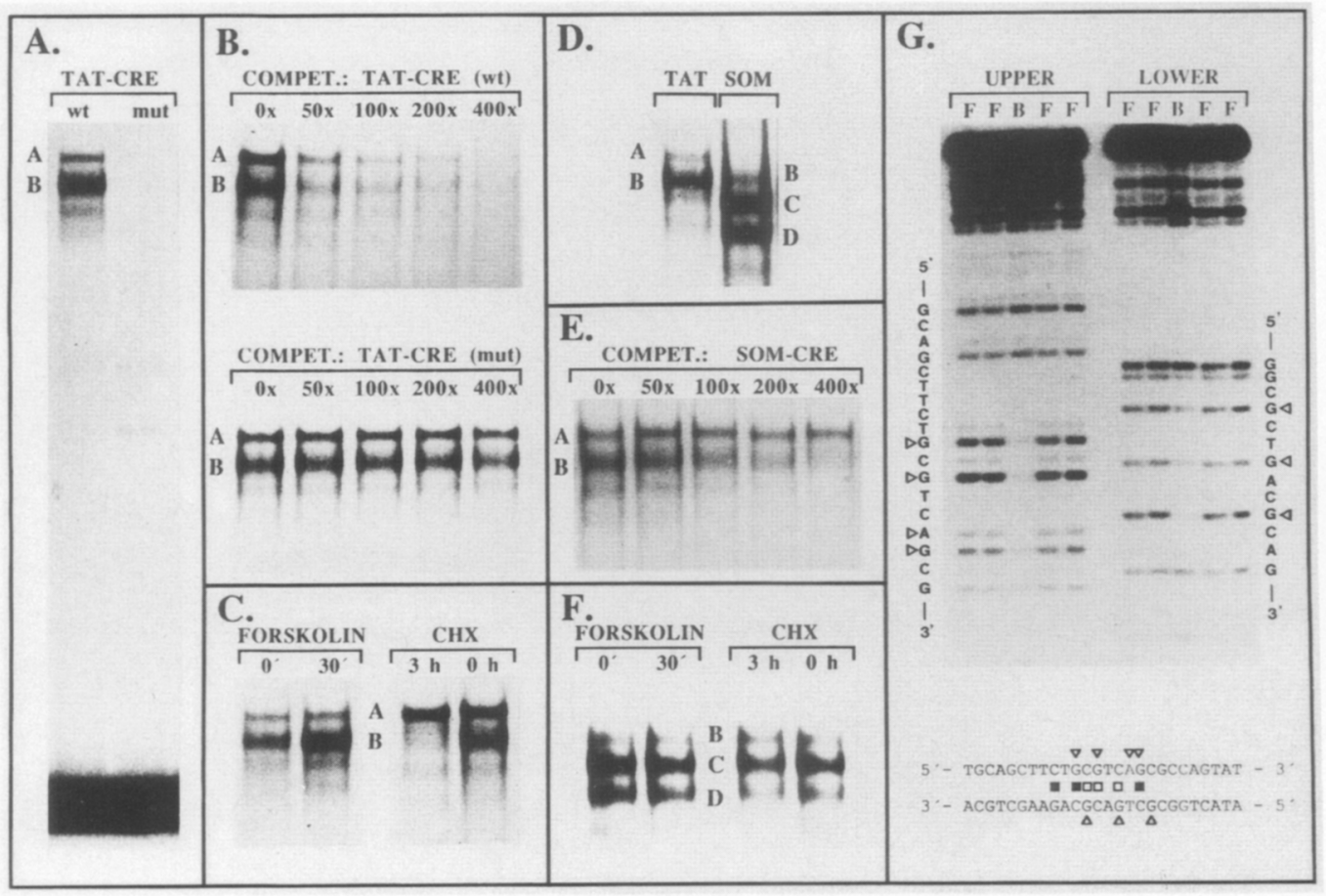

Figure 7. In vitro analyses of protein-DNA interactions at the TAT-CRE. Nuclear extract protein $(25 \mu \mathrm{g})$ was incubated on ice with sonicated herring sperm DNA $(100 \mu \mathrm{g} / \mathrm{ml})$ and $\sim 5$ fmoles of labeled fragment carrying the TAT-CRE, as detailed in Materials and methods. After the binding reaction, samples were loaded onto a $4 \%$ native polyacrylamide gel and electrophoresed at $9 \mathrm{~V} / \mathrm{cm}$. The gels were removed from the glass plates, dried, and exposed to X-ray films. $(A)$ Two strong complexes $(\mathrm{A}$ and $\mathrm{B})$ can be detected with the wild-type (wt) TAT-CRE sequence, but neither forms with the mutated (mut) version. (B) Formation of complexes A and B can be specifically competed. The indicated amounts of unlabeled competitor fragments (wt or mut) were added to the reaction mixture. Numbers indicate the molar excess of unlabeled competitor DNA over labeled fragment. $(C)$ Complex B responds to forskolin induction and is sensitive to CHX. The TAT-CRE fragment (wt) was end-labeled and incubated with nuclear extracts prepared either from untreated, forskolin-induced, or CHX-treated cells. $(D)$ Three complexes (B-D) can be detected with the somatostatin CRE. Only one comigrates with complex B of the TAT-CRE. (TAT) Labeled TAT-CRE; (SOM) labeled somatostatin CRE. (E) The somatostatin CRE specifically competes for complex B but not for complex A of the TAT-CRE. Numbers are as in $B$. $(F)$ None of the somatostatin-specific complexes responds to forskolin or is sensitive to CHX. The somatostatin CRE fragment was end-labeled and incubated with the same extracts shown in $C .(G)$ Methylation interference assay for complex B. A preparative gel retardation experiment with partially methylated TAT-CRE fragment (wt) and FTO-2B nuclear extracts was carried out. DNA from complexes (bound, B) and from the unretarded fraction (free, F) was isolated as detailed in Materials and methods, cleaved with piperidine, and separated on a $10 \%$ denaturing polyacrylamide gel. The nucleotide sequence of the upper and lower strand are indicated at left and right, respectively. $(\Delta)$ Purine residues whose methylation interferes with complex formation. The methylation interference pattern of complex B is summarized at bottom. The in vivo DMS footprint at the TAT-CRE is indicated in the center, as detailed in Fig. 2.

diated by the catalytic subunit of PK-A (Schmid et al. 1987; Büchler et al. 1988). Protein phosphorylation, which leads to increased DNA-binding activity of the TAT-CRE-recognizing factor upon cAMP induction, and dephosphorylation by specific phosphatases, which causes the subsequent decrease, is one possible explanation of our observations.

In contrast to the results obtained with the TATCRE, binding activity to the somatostatin CRE is not affected by treatment of FTO-2B cells with forskolin or $\mathrm{CHX}$ (cf. Fig. 7,C and F). In addition, it has been shown that phosphorylation of the CRE-binding protein (CREB) increases transcriptional efficacy (Yamamoto et al. 1988), rather than influencing its binding activity in vitro (Montminy and Bilezikjian 1987). More recently, it has been demonstrated that phosphorylation of CREB at a specific serine residue mediated by the catalytic subunit of PK-A is responsible for this increase in transcrip- tional efficacy (Gonzalez and Montminy 1989). At present, we cannot answer the question whether the protein forming complex $B$ with the TAT-CRE is related to CREB or not. If CREB is interacting with the TAT-CRE, one must postulate that both forskolin induction and CHX treatment affect the affinity of CREB to the TAT-CRE but do not affect binding to the somatostatin CRE. We anticipate that purification of nuclear factors interacting with the TAT-CRE and the somatostatin CRE by DNA-affinity chromatography (Kadonaga and Tjian 1986) will resolve the relationship between complexes A-D.

Increased binding of a nuclear factor after cAMP stimulation to the region of the phosphoenolpyruvate carboxykinase (PEPCK) gene known to contain a CRE has been reported by Lee et al. (1988). Its relationship to the TAT-CRE-binding protein is unclear; however, both TAT and PEPCK are predominantly expressed in the 
same cell type. Furthermore, phosphorylation-dependent activation of binding of a transcription factor has been reported in the adenovirus system (Bagchi et al. 1989).

In this study we have been able to correlate in vivo DNA binding with transcriptional activation. This is reminiscent of the action of the steroid hormone receptors. Following glucocorticoid administration, protein-DNA interactions can be demonstrated at the TAT-GRE, indicative of receptor binding (Becker et al. 1986), and transcription is stimulated. However, it is different from the case of the c-fos-SRE, where an apparently fixed protein-DNA complex mediates signal transduction (see Table 1; Herrera et al. 1989). We reason that the in vivo footprint at the TAT-CRE in the absence of cAMP reflects basal level activity of this DNA-binding protein and correlates with basal level transcription. The observation that the unstimulated occupancy of the TAT-CRE is subject to turnover in vivo was unexpected. Because cAMP-mediated signal transduction through this site involves changes in DNA-binding activity of a protein, we conclude that the basal level occupant of the site must be subject to turnover to make the site responsive. This characteristic of occupancy turnover may distinguish the mode of signal transduction employed by steroid hormones from that described here (see Table 1). Whereas the two pathways both deliver increased concentrations of DNA-binding activity to the respective response elements, they may differ by regulation at a post-translational level. The classic model of steroid hormone action involves the direct activation by ligand binding of a receptor to establish a DNase I HS site in chromatin. Transcription is stimulated and persists as long as hormone is present. In the case described here, transcriptional stimulation correlates with a post-translational stimulation of a factor's
DNA-binding activity. This takes place at a preexisting DNase I HS site, which is reflective of protein binding to the TAT-CRE in the uninduced state. Even in the continued presence of cAMP inducers (forskolin or cAMP analogs), DNA-binding activity of this protein and transcriptional stimulation diminish subsequently (Hashimoto et al. 1984; this work and data not shown). A comparison of strategies of signal transduction is presented in Table 1.

Although we show evidence indicating that the same DNA-binding protein mediates both basal level and cAMP responses, it remains unclear whether the two functions represent different levels of DNA-binding activity achieved by the same pathway or two different pathways that both influence the DNA-binding activity of this protein. Evidence places PK-A in the pathway of cAMP stimulation of the TAT gene, and a close correlation of basal gene transcription and PK-A activity has already been demonstrated for other cAMP-regulated genes (Day et al. 1989; Grove et al. 1989; Mellon et al. 1989).

In vitro analysis of proteins by DNA-binding assays has been a powerful tool to characterize transcription factors. Nevertheless, it is often difficult to correlate in vitro observations with the situation in a living cell (Becker et al. 1987). This is particularly relevant for the analysis of factors binding to CREs, given the DNA sequence homologies between different CREB-, ATF-, and AP1-binding sites and the emerging observation that Fos, Jun, CREB, and ATF are members of a large family of proteins that contain very similar DNA-binding and dimerization domains (Hai et al. 1988; Hoeffler et al. 1988; Gonzalez et al. 1989; Hai et al. 1989; Hirai et al. 1989; Maekawa et al. 1989; Ryder et al. 1989; for review, see Mitchell and Tjian 1989/. The TAT-CRE is almost identical to functionally related sequences in the proto-

Table 1. Comparison of different signal transduction pathways

\begin{tabular}{|c|c|c|c|}
\hline & \multicolumn{2}{|c|}{ Signal transduction via induced DNA binding } & \multirow{2}{*}{$\begin{array}{l}\text { Signal transduction via fixed } \\
\text { protein-DNA complexes at } \\
\text { the c-fos SRE }\end{array}$} \\
\hline & steroid hormone action & $\begin{array}{l}\text { occupancy turnover at } \\
\text { the TAT-CRE }\end{array}$ & \\
\hline $\begin{array}{l}\text { Protein-DNA interactions } \\
\text { in chromatin }\end{array}$ & $\begin{array}{l}\text { hormone-dependent HS } \\
\text { site; no protein bound at } \\
\text { responsive sites in the } \\
\text { absence of hormone }\end{array}$ & $\begin{array}{l}\text { constitutive HS site; basal } \\
\text { level of protein binding } \\
\text { correlates with basal level } \\
\text { of gene transcription }\end{array}$ & $\begin{array}{l}\text { constitutive HS site; } \\
\text { constitutive protein } \\
\text { binding to responsive site }\end{array}$ \\
\hline $\begin{array}{l}\text { Signal-dependent changes } \\
\text { in DNA-binding activity }\end{array}$ & $\begin{array}{l}\text { direct activation of DNA } \\
\text { binding by the hormone }\end{array}$ & $\begin{array}{l}\text { activation of PK-A; post- } \\
\text { translational modification } \\
\text { to increase DNA-binding } \\
\text { activity }\end{array}$ & not detectable \\
\hline Transcriptional response & $\begin{array}{l}\text { activated receptor } \\
\text { establishes transcription } \\
\text { factor complex that } \\
\text { stimulates transcription }\end{array}$ & $\begin{array}{l}\text { increased DNA-binding } \\
\text { activity correlates with } \\
\text { increased transcriptional } \\
\text { activity }\end{array}$ & $\begin{array}{l}\text { as yet undetermined } \\
\text { modification of fixed } \\
\text { protein-DNA complex } \\
\text { activates transcription }\end{array}$ \\
\hline Down-regulation & $\begin{array}{l}\text { transcription is stimulated } \\
\text { as long as hormone is } \\
\text { present }\end{array}$ & $\begin{array}{l}\text { stimulation of transcription } \\
\text { is transient due to } \\
\text { occupancy turnover at the } \\
\text { responsive site }\end{array}$ & $\begin{array}{l}\text { auto-regulatory feedback; } \\
\text { transcription rate is } \\
\text { down-regulated }\end{array}$ \\
\hline
\end{tabular}


oncogene c-fos ( -301 to -291 ; Fisch et al. 1989; Shaw et al. 1989) and in the human proenkephalin gene $(-94$ to -84 ; Comb et al. 1986, 1988). Purified AP-1 binds to these sequences in vitro (Piette and Yaniv 1987; Comb et al 1988; Shaw et al. 1989), despite the absence of functional or in vivo evidence that relates AP-1 to the CAMP responsiveness of these genes. Consequently, we have performed in vivo analysis of DNA-protein interactions and confirmed the effects observed in vivo with in vitro data. Thus, we have generated criteria with which to identify the correct factor as a purified protein or an isolated cDNA clone.

\section{Materials and methods}

\section{Plasmid constructs}

Synthetic oligonucleotides used in transfection and gel retardation experiments were synthesized on an Applied Biosystems synthesizer. Oligonucleotides covering the wild-type or the mutated TAT-CRE sequence were concatemerized and inserted into the $X b a I$ site of pBLCAT2 (Luckow and Schütz 1987). Recombinant plasmids containing six direct repeats of either oligonucleotide in the sense orientation were used in the transient transfection experiments. Constructs used for stable transfections are based on the plasmid TATCAT $-4289 /+62$, which is described in Boshart et al. (1990). The end points of TATCAT -3675 and TATCAT -3628 correspond to SphI and Avall restriction sites in the TAT sequence, respectively. TATCAT - 3675/M3 was generated by the oligonucleotide cassette technique (Grundström et al. 1985). A 131-bp SphI $(-3675)-X b a I(-3544)$ fragment was replaced by 14 assembled oligonucleotides that contained a triple-point mutation at the TAT-CRE. All constructions were verified by restriction enzyme digestions and plasmid sequencing (Chen and Seeburg 1985). The neo gene driven by the TK promoter was used as a selectable marker (pTKneo; M. Boshart, unpubl.).

\section{Cell culture}

FTO-2B cells were grown to confluency in DMEM/Ham's F12 (1:1) with $10 \%$ fetal calf serum, $2 \mathrm{mM}$ glutamine, $100 \mathrm{U} / \mathrm{ml}$ penicillin, $100 \mu \mathrm{g} / \mathrm{ml}$ streptomycin, and $10 \mathrm{mM}$ HEPES (pH 7.4). $\mathrm{XC}$ cells were cultured in DMEM instead of DMEM/Ham's F12. Prior to harvesting, cells were incubated for $12-18 \mathrm{hr}$ in serum-free medium, followed by a change to medium that contained $10 \mu \mathrm{M}$ forskolin (Calbiochem) or $0.1 \%$ ethanol as solvent control. Induction times ranged from 30 to $250 \mathrm{~min}$. For $\mathrm{CHX}$ experiments, cells were treated for 45-250 min with $50 \mu \mathrm{g} / \mathrm{ml}$ $\mathrm{CHX}$ (Sigma) after overnight incubation in serum-free medium.

\section{DNA transfections and generation of stably transfected cell lines}

FTO-2B cells were transfected by electroporation (Fromm et al. 1985; Chu et al. 1987). Transfections and CAT assays were performed as described in detail by Boshart et al. (1990). For stable transfections, TATCAT constructs were cotransfected with the selectable neo gene into FTO-2B cells by electroporation. Vector sequences of both plasmids were removed by gel purification prior to transfection. After 3 days, culture medium was changed to DMEM/Ham's F12, including $800 \mu \mathrm{g} / \mathrm{ml} \mathrm{G} 418$ (GIBCO). After 10 additional days, G 418-resistant cells $(\geqslant 850$ individual colonies per transfection) were pooled, split onto separate dishes, and used for RNA preparation after forskolin induction.

\section{Mapping of DNase I HS sites}

FTO-2B and XC cells were treated with serum-free media for 12 $\mathrm{hr}$ and induced with dexamethasone $(1 \mu \mathrm{M})$ or cAMP $(0.5 \mathrm{mM}$ 8-4-chlorophenylthio-cAMP; Boehringer-Mannheim) for $1 \mathrm{hr}$. All other methods were as described previously (Jantzen et al. 1987), except that a $1 \%$ agarose gel was employed and soakblotted to Pall Biodyne B according to the manufacturer's recommendations. The probe EB670 was cloned into Bluescribe $\mathrm{Ml3}^{-}$(Stratagene) and used as the template for T3-RNA polymerase transcription by standard procedures (Melton et al. 1984).

\section{Genomic footprinting, probe synthesis, and hybridization}

Routinely, one to two dishes $\left(15 \mathrm{~cm}, 0.5 \times 10^{8}\right.$ to $1 \times 10^{8}$ cells $)$ were collected by mild trypsinization and resuspended in $1 \mathrm{ml}$ of serum-free medium or in medium containing either $10 \mu \mathrm{M}$ forskolin, $50 \mu \mathrm{g} / \mathrm{ml} \mathrm{CHX}$, or both. The subsequent steps were carried out as described in detail by Becker and Schütz (1988). The probe HS127 (Fig. 2) was cloned into SacI- and SphI-digested Bluescribe $\mathrm{M} 13^{-}$. The vector and the probe fragment were treated with T4-DNA polymerase to generate blunt ends according to Maniatis et al. (1982). Identity and orientation were verified by supercoil sequencing (Chen and Seeburg 1985). Synthesis of single-stranded cDNA probes of high specific activity from RNA templates by reverse transcription was as described (Weih et al. 1988).

Hybridizations were performed according to Church and Gilbert (1984), with modifications (Becker and Schütz 1988), except that presaturation of vector-specific sequences with sheared single-stranded vector DNA was omitted.

\section{RNA analyses}

RNA was prepared according to Cathala et al. (1983). Correctly initiated transcripts of stably transfected TATCAT constructs were quantitated by a ribonuclease protection experiment (Melton et al. 1984). Total RNA (40 $\mu \mathrm{g}$ ) was hybridized with 10 fmoles $\left(6 \times 10^{5} \mathrm{cpm}\right)$ of a uniformly labeled and gel-purified SP6 transcript, covering positions -108 to +216 of pTATCAT (Jantzen et al. 1987), and digested for $1 \mathrm{hr}$ at $30^{\circ} \mathrm{C}$ with $10 \mu \mathrm{g} / \mathrm{ml}$ RNase $A$ and $100 \mathrm{U} / \mathrm{ml}$ RNase Tl. Northern gels were run with $10 \mu \mathrm{g}$ of total RNA per lane as described by Schmid et al. (1987).

\section{Nuclear run-on analysis}

FTO-2B cells for run-on analysis were either induced with 10 $\mu \mathrm{M}$ forskolin or uninduced. The run-on transcription reactions were performed as described previously (Stewart and Schütz 1987). The following plasmids were immobilized on the filters: for TAT, 0.5 pmole each of pTATEHO.95, pTATEH2.45, and pTATEE 1.05 (Hashimoto et al. 1984); for GAPDH, 0.5 pmole of pGAPDH (Fort et al. 1985); for Bluescribe, 1.5 pmole was employed.

\section{Preparation of nuclear extracts}

Nuclear extracts were prepared as described by Dignam et al. (1983), with modifications (Wildeman et al. 1984). The extracts were finally dialyzed against $20 \mathrm{~mm} \mathrm{HEPES} / \mathrm{KOH}$ (pH 7.9), $20 \%$ glycerol, $20 \mathrm{mM} \mathrm{KCl}, 2 \mathrm{mM} \mathrm{MgCl} 2,0.2 \mathrm{~mm}$ EDTA, $0.5 \mathrm{~mm}$ DTT, and $0.5 \mathrm{mM}$ PMSF. Nuclear extracts from uninduced and forskolin-induced FTO-2B cells were prepared in the presence of phosphatase inhibitors. Briefly, after incubation on ice for 10 min in hypotonic buffer, cells were collected by centrifugation and resuspended in hypotonic buffer containing in addition 20 
$\mathrm{mM} \mathrm{Na}_{2} \mathrm{HPO}_{4}(\mathrm{pH} 7.2), 5 \mathrm{~mm} \mathrm{NaF}$, and $0.2 \mathrm{~mm}\left(\mathrm{NH}_{4}\right)_{6} \mathrm{Mo}_{7} \mathrm{O}_{24}$. These inhibitors were also added to all buffers used in the succeeding preparation steps.

\section{Gel retardation assays}

The oligonucleotides used in the gel retardation assays (Fig. 3B) were cloned into Bluescribe vectors. The sequence of the somatostatin CRE oligonucleotide is given for the upper strand from position -56 to -31 : $5^{\prime}$-TCCTTGGCTGACGTCAGAGAGAGAGT-3'. After linearization with either HindIII or EcoRI within the polylinker, the resulting 5'-protruding ends were filled with Klenow enzyme and labeled with $\left[\alpha-{ }^{32} \mathrm{P}\right] \mathrm{dATP}$. The labeled DNA was restricted with EcoRI or HindIII, respectively; the fragment of interest was purified over a $10 \%$ polyacrylamide gel and eluted from the gel overnight at $37^{\circ} \mathrm{C}$ (Maniatis et al. 1982). Twenty-five micrograms of nuclear protein was routinely incubated with $1 \mu \mathrm{g}$ of sonicated herring sperm DNA in binding buffer consisting of $10 \mathrm{mM}$ HEPES/KOH $/ \mathrm{pH}$ $7.9 \mid, 15 \%$ glycerol, $30 \mathrm{mM} \mathrm{KCl}, 5 \mathrm{~mm} \mathrm{MgCl}_{2}, 4 \mathrm{mM}$ spermidine, $0.1 \mathrm{~mm}$ EDTA, $0.25 \mathrm{~mm}$ DTT, and $0.25 \mathrm{mM}$ PMSF in a total volume of $9 \mu \mathrm{l}$ for $15 \mathrm{~min}$ on ice. To this, $1 \mu \mathrm{l}(5 \mathrm{fmoles})$ of specific end-labeled fragment $(20,000 \mathrm{cpm} / \mu \mathrm{l})$ was added, and incubation was continued for $15 \mathrm{~min}$ on ice. For competition experiments, $0.25-2$ pmoles (50- to 400 -fold molar excess) of unlabeled DNA fragments was added to the reaction mixture shortly before the labeled fragment. Samples were loaded onto $4 \%$ native polyacrylamide gels and separated by electrophoresis in $30 \mathrm{~mm}$ Tris-borate buffer $(\mathrm{pH} 8.4)$ at $9 \mathrm{~V} / \mathrm{cm}$. Gels were dried and autoradiographed (Fried and Crothers 1981; Garner and Revzin 1981).

\section{Methylation interference studies}

End-labeled DNA fragments were partially methylated with DMS by standard procedures (Maxam and Gilbert 1980). The amount of DNA used for 10 analytical gel retardation reactions was loaded onto a preparative $4 \%$ polyacrylamide gel and, after separation, visualized by autoradiography. Material corresponding to bound and free fractions was cut out, and DNA was recovered by isotachophoresis (Öfverstedt et al. 1984). After phenol/chloroform $(1: 1)$ extraction and addition of carrier, DNA was precipitated with ethanol. Samples were subsequently cleaved with piperidine, ethanol-precipitated, and dried for several hours in the SpeedVac concentrator. Equal amounts of radioactive material resuspended in formamide loading buffer were applied to a $10 \%$ sequencing gel (Siebenlist and Gilbert 1980).

\section{Acknowledgments}

We thank Dr. P.B. Becker for a detailed introduction to the genomic footprinting technique; Drs. M. Nichols, W. Schmid, and P. Shaw for critically reading the manuscript; B. Müller for stimulating discussions; W. Fleischer for oligonucleotide synthesis; and S. Mähler for photography. This work was supported by the Deutsche Forschungsgemeinschaft and the Fonds der Chemischen Industrie.

The publication costs of this article were defrayed in part by payment of page charges. This article must therefore be hereby marked "advertisement" in accordance with 18 USC section 1734 solely to indicate this fact.

\section{Note added in proof}

The paper referred to as D. Nitsch et al. (in prep.) is now published: Nitsch, D., A.F. Stewart, M. Boshart, R. Mestril, F. Weih, and G. Schütz. 1990. Chromatin structures of the rat ty- rosine aminotransferase gene relate to the function of its cisacting elements. Mol. Cell. Biol. 10: 3334-3342.

Sequence data described in this paper have been submitted to EMBL/GenBank Data Libraries under accession number M34257.

\section{References}

Bagchi, S., P. Raychaudhuri, and J.R. Nevins. 1989. Phosphorylation-dependent activation of the adenovirus-inducible E2F transcription factor in a cell-free system. Proc. Natl. Acad. Sci. 86: 4352-4356.

Beato, M. 1989. Gene regulation by steroid hormones. Cell 56: 335-344.

Becker, P.B., R. Renkawitz, and G. Schütz. 1984. Tissue-specific DNase I-hypersensitive sites in the $5^{\prime}$-flanking sequences of the tryptophan oxygenase and the tyrosine aminotransferase genes. EMBO J. 3: 2015-2020.

Becker, P.B., B. Gloss, W. Schmid, U. Strähle, and G. Schütz. 1986. In vivo protein/DNA-interactions within a glucocorticoid response element requires presence of the hormone. Nature 324: 686-688.

Becker, P.B., S. Ruppert, and G. Schütz. 1987. Genomic footprinting reveals cell type-specific DNA binding of ubiquitous factors. Cell 51: 435-443.

Becker, P.B. and G. Schütz. 1988. Genomic footprinting Genetic engineering, principles and methods (ed. J.K. Setlow). Plenum Press, New York. 10: 1-19.

Bokar, J.A., W.J. Roesler, G.R. Vandenbark, D.M. Kaetzel. R.W. Hanson, and J.H. Nilson. 1988. Characterization of the cAMP responsive elements from the genes for the $\alpha$-subunit of glycoprotein hormones and phosphoenolpyruvate carboxykinase (GTP). J. Biol. Chem. 263: 19740-19747.

Boshart, M., F. Weih, A. Schmidt, and G. Schütz. 1990. A cyclic AMP response element mediates repression of tyrosine aminotransferase gene expression by the tissue specific extinguisher locus Tse-1. Cell 61: 905-916.

Büchler, W., U. Walter, and S.M. Lohmann. 1988. Catalytic subunit of cAMP-dependent protein kinase is essential for cAMP-mediated mammalian gene expression. FEBS Lett. 228: 27-32.

Cathala, G., J. Savouret, B. Mendez, B.L. West, M. Karin, J.A. Martial, and J.D. Baxter. 1983. A method for isolating intact, translationally active ribonucleic acid. DNA 2: 329-335.

Chen, E.Y. and P.H. Seeburg. 1985. Supercoil sequencing: A fast and simple method for sequencing plasmid DNA. DNA 4: $165-170$.

Chu, G., H. Hoyakawa, and P. Berg. 1987. Electroporation for the efficient transfection of mammalian cells with DNA. Nucleic Acids Res. 15: 1311-1326.

Church, G.M. and W. Gilbert. 1984. Genomic sequencing. Proc. Natl. Acad. Sci. 81: 1991-1995.

Comb, M., N.C. Birnberg, A. Seasholtz, E. Herbert, and H.M. Goodman. 1986. A cyclic AMP- and phorbol ester-inducible DNA element. Nature 323: 353-356.

Comb, M., N. Mermod, S.E. Hyman, J. Pearlberg, M.E. Ross, and H.M. Goodman. 1988. Proteins bound at adjacent DNA elements act synergistically to regulate human proenkephalin cAMP inducible transcription. EMBO J. 7:37393805.

Day, R.N., J.A. Walder, and R.A. Maurer. 1989. A protein kinase inhibitor gene reduces both basal and multihormone-stimulated prolactin gene transcription. J. Biol. Chem. 264: 431436.

Dean, D.C., M.S. Blakeley, R.F. Newby, P. Ghazal, L. Hennighausen, and S. Bourgeois. 1989. Forskolin inducibility and 
tissue-specific expression of the fibronectin promoter. Mol. Cell. Biol. 9: 1498-1506.

Delegeane, A.M., L.H. Ferland, and P.L. Mellon. 1987. Tissue specific enhancer of the human glycoprotein hormone $\alpha$ subunit gene: Dependence on cyclic AMP-inducible elements. Mol. Cell. Biol. 7: 3994-4002.

Dignam, J.D., R.M. Lebovitz, and R.G. Roeder. 1983. Accurate transcription initiation by RNA polymerase II in a soluble extract from isolate mammalian nuclei. Nucleic Acids Res. 11: $1475-1489$.

Edelman, A.M., D.K. Blumenthal, and E.G. Krebs. 1987. Protein serine/threonine kinases. Annu. Rev. Biochem 56: 567613.

Evans, R.M. 1988. The steroid and thyroid hormone receptor superfamily. Science 240: 889-895.

Fisch, T.M., R. Prywes, M.C. Simon, and R.G. Roeder. 1989. Multiple sequence elements in the c-fos promoter mediate induction by cAMP. Genes Dev. 3: 198-211.

Fort, P., L. Marty, M. Piechaczyk, S. El Sabrouty, C. Dani, P. Jeanteur, and J.M. Blanchard. 1985. Various rat adult tissues express only one major mRNA species from the glyceraldehyde-3-phosphate dehydrogenase multigenic family. $\mathrm{Nu}$ cleic Acids Res. 13: 1431-1442.

Fried, M. and D.M. Crothers. 1981. Equilibria and kinetics of lac repressor-operator interactions by polyacrylamide electrophoresis. Nucleic Acids Res. 9: 6506-6525.

Fromm, M., L.P. Taylor, and V. Walbot. 1985. Expression of genes transferred into monocot and dicot plant cells by electroporation. Proc. Natl. Acad. Sci. 82: 5824-5828.

Garner, M.M. and A. Revzin. 1981. A gel electrophoresis method for quantifying the binding of proteins to specific DNA regions. Application to components of the $E$. coli lactose operon regulatory system. Nucleic Acids Res. 9: 30473060.

Gilbert, W., A. Maxam, and A. Mirzabekov. 1976. Contacts between the LAC repressor and DNA revealed by methylation. Control of ribosome synthesis, Alfred Benzon Symposium $I X$. (ed. N.O. Kjelgaard and O. Maaloe), pp. 139-148. Academic Press, New York.

Gilman, A.G. 1987. G proteins: Transducers of receptor-generated signals. Annu. Rev. Biochem 56: 615-649.

Gonzalez, G.A. and M.R. Montminy. 1989. Cyclic AMP stimulates somatostatin gene transcription by phosphorylation of CREB at serine 133. Cell 59: 675-680.

Gonzalez, G., K.K. Yamamoto, W.H. Fischer, D. Karr, P. Menzel, W. Biggs III, W.W. Vale, and M.R. Montminy. 1989. A cluster of phosphorylation sites on the cyclic AMP-regulated nuclear factor CREB predicted by its sequence. Nature 337: 749-752.

Green, S. and P. Chambon, 1988. Nuclear receptors enhance our understanding of transcription regulation. Trends Genet. 4: 309-314.

Grove, J.R., P.J. Deutsch, D.J. Price, J.F. Habener, and J. Avruch. 1989. Plasmids encoding PKI (1-31), a specific inhibitor of cAMP-stimulated gene expression, inhibit the basal transcriptional activity of some but not all cAMP-regulated DNA response elements in JEG-3 cells. I. Biol. Chem. 264: 19506-19513.

Grundström, T., W.M. Zenke, M. Wintzerith, H.W.D. Matthes, and P. Chambon. 1985. Oligonucleotide-directed mutagenesis by microscale "shot-gun" gene synthesis. Nucleic Acids Res. 9: 3305-3316.

Hai, T., F. Liu, E.A. Allegretto, M. Karin, and M.R. Green. 1988. A family of immunologically related transcription factors that includes multiple forms of ATF and AP-1. Genes Dev. 2: 1216-1226.
Hai, T., F. Liu, W.J. Coukos, and M.R. Green. 1989. Transcription factor ATF cDNA clones: An extensive family of leucine zipper proteins able to selectively form DNA-binding heterodimers. Genes Dev. 3: 2083-2090.

Hargrove, J.L. and D.K. Granner. 1985. Biosynthesis and intracellular processing of tyrosine aminotransferase. In "Transaminases". (ed. P. Christen and P.E. Metzler), pp. 511-532. John Wiley and Sons, New York.

Hashimoto, S., W. Schmid, and G. Schütz. 1984. Transcriptional activation of the rat liver tyrosine aminotransferase gene by cAMP. Proc. Natl. Acad. Sci. 81: 6637-6641.

Herrera, R.E., P.E. Shaw, and A. Nordheim. 1989. Occupation of the c-fos serum response element in vivo by a multi-protein complex is unaltered by growth factor induction. Nature 340: $68-70$.

Hirai, S.-I., R.-P. Ryseck, F. Mechta, R. Bravo, and M. Yaniv. 1989. Characterization of junD: A new member of the jun proto-oncogene family. EMBO J. 8: 1433-1439.

Hoeffler, J.P., T.E. Meyer, Y. Yun, J.L. Jameson, and F. Habener. 1988. Cyclic AMP-responsive DNA-binding protein: Structure based on a cloned placental cDNA. Science 242: 14301433.

Hokin, L.E. 1985. Receptors and phosphoinositide-generated second messengers. Annu. Rev. Biochem 54: 205-235.

Jantzen, H.M., U. Strähle, B. Gloss, F. Stewart, W. Schmid, M. Boshart, R. Miksicek, and G. Schütz. 1987. Cooperativity of glucocorticoid response elements located far upstream of the tyrosine aminotransferase gene. Cell 49: 29-38.

Johnsrud, L. 1978. Contacts between Escherichia coli RNA polymerase and a lac operon promoter. Proc. Natl. Acad. Sci. 75: 5314-5318.

Jones, N.C., P.W.J. Rigby, and E.B. Ziff. 1988. Trans-acting protein factors and the regulation of eukaryotic transcription: Lessons from studies on DNA tumor viruses. Genes Dev. 2: $267-281$.

Kadonaga, J.T. and R. Tjian. 1986. Affinity purification of sequence-specific DNA binding proteins. Proc. Natl. Acad. Sci. 83: 5889-5893.

Killary, A.M. and R.E.K. Fournier. 1984. A genetic analysis of extinction: Trans-dominant loci regulate expression of liver-specific traits in hepatoma hybrid cells. Cell 38: 523534.

Lee, C.Q., H.A. Miller, D. Schlichter, J.N. Dong, and W.D. Wicks. 1988. Evidence for a cAMP-dependent nuclear factor capable of interacting with a specific region of a eukaryotic gene. Proc. Natl. Acad. Sci. 85: 4223-4227.

Luckow, B. and G. Schütz. 1987. CAT constructions with multiple unique restriction sites for the functional analysis of eukaryotic promoters and regulatory elements. Nucleic Acids Res. 15: 5490.

Maekawa, T., H. Sakura, C. Kanei-Ishii, T. Sudo, T. Yoshimura, J. Fujisawa, M. Yoshida, and S. Ishii. 1989. Leucine zipper structure of the protein CRE-BP1 binding to the cyclic AMP response element in brain. EMBO J.8: 2023-2038.

Maniatis, T., E.F. Fritsch, and J. Sambrook. 1982. Molecular cloning: A laboratory manual. Cold Spring Harbor Laboratory Press, Cold Spring Harbor, New York.

Maxam, A.M. and W. Gilbert. 1980. Sequencing end-labeled DNA with base-specific chemical cleavages. Methods Enzymol. 65: 499-560.

Mellon, P.L., C.H. Clegg, L.A. Correl, and G.S. McKnight. 1989. Regulation of transcription by cyclic AMP-dependent protein kinase. Proc. Natl. Acad. Sci. 86: 4887-4891.

Melton, D.A., P.A. Krieg, M.R. Rebagliati, T. Maniatis, K. Zinn, and M.R. Green. 1984. Efficient in vitro synthesis of biologically active RNA and RNA-hybridization probes from 
plasmids containing a bacteriophage SP6 promoter. Nucleic Acids Res. 12: 7035-7056.

Mitchell, P.J. and R. Tjian. 1989. Transcriptional regulation in mammalian cells by sequence-specific DNA binding proteins. Science 245: 371-378.

Montminy, M.R. and L.M. Bilezikjian. 1987. Binding of a nuclear protein to the cyclic-AMP response element of the somatostatin gene. Nature 328: 175-178.

Montminy, M.R., K.A. Sevarino, J.A. Wagner, G. Mandel, and R.H. Goodman. 1986. Identification of a cyclic-AMP responsive element within the rat somatostatin gene. Proc. Natl. Acad. Sci. 83: 6682-6686.

Öfverstedt, L.G., K. Hammarström, N. Balgobin, S. Hjerten, U. Petterson, and J. Chattopadhyaya. 1984. Rapid and quantitative recovery of DNA fragments from gels by displacement electrophoresis (isotachophoresis). Biochim. Biophys. Acta. 782: $120-126$.

Philipsen, J.N.J., B.C. Hennis, and G. AB. 1988. In vivo footprinting of the estrogen-inducible vitellogenin II gene from chicken. Nucleic Acids Res. 16: 9663-9676.

Piette, J. and M. Yaniv. 1987. Two different factors bind to the $\alpha$-domain of the polyoma virus enhancer, one of which also interacts with the SV40 and c-fos enhancers. EMBO $J$. 6: $1331-1337$.

Quinn, P.G., T.W. Wong, M.A. Magnuson, J.B. Shabb, and D.K. Granner. 1988. Identification of basal and cyclic AMP regulatory elements in the promoter of the phosphoenolpyruvate carboxykinase gene. Mol. Cell. Biol. 8: 3467-3475.

Ryder, K., A. Lanahan, E. Perez-Albuerne, and D. Nathans. 1989. Jun-D: A third member of the Jun gene family. Proc. Natl. Acad. Sci. 86: 1500-1503.

Schmid, E., W. Schmid, D. Mayer, B. Jastorff, and G. Schütz. 1987. Transcriptional activation of the tyrosine aminotransferase gene by glucocorticoids and cAMP in primary hepatocytes. Eur. J. Biochem. 165: 499-506.

Seamon, K.B., W. Padgett, and J.W. Daly. 1981. Forskolin: Unique diterpene activator of adenylate cyclase in membranes and in intact cells. Proc. Natl. Acad. Sci. 78: 33633367.

Shaw, P.E., S. Frasch, and A. Nordheim. 1989. Repression of c-fos transcription is mediated through p67-SRF bound to the SRE. EMBO I. 8: 2567-2574.

Siebenlist, U. and W. Gilbert. 1980. Contacts between E. coli RNA polymerase and an early promoter of phage T7. Proc. Natl. Acad. Sci. 77: 122-126.

Silver, B.J., J.A. Bokar, J.B. Virgin, E.A. Vallen, A. Milsted, and J.H. Nilson. 1987. Cyclic AMP regulation of the human glycoprotein hormone $\alpha$-subunit gene is mediated by an 18base-pair element. Proc. Natl. Acad. Sci. 84: 2198-2202.

Stewart, A.F. and G. Schütz. 1987. Camptothecin-induced in vivo topoisomerase I cleavages in the transcriptionally active tyrosine aminotransferase gene. Cell 50: 1109-1117.

Strähle, U., W. Schmid, and G. Schütz. 1988. Synergistic action of the glucocorticoid receptor with transcription factors. EMBO I. 7: 3389-3395.

Svoboda, J. 1960. Presence of chicken tumor virus in the sarcoma of the adult rat inoculated after birth with Rous sarcoma virus. Nature 186: 980-981.

Treisman, R. 1985. Transient accumulation of c-fos RNA following serum stimulation requires a conserved 5 ' element and c-fos 3' sequences. Cell 42: 889-902.

Tsukada, T., J.S. Fink, G. Mandel, and R.H. Goodman. 1987. Identification of a region in the human vasoactive intestinal polypeptide gene responsible for regulation by cAMP. J. Biol. Chem. 262: 8743-8747.

Weih, F., A.F. Stewart, and G. Schütz. 1988. A novel and rapid method to generate single stranded DNA probes for genomic footprinting. Nucleic Acids Res. 16: 1628.

Wijnholds, J., J.N.J. Philipson, and G. AB. 1988. Tissue-specific and steroid-dependent interaction of transcription factors with the oestrogen-inducible apoVLDL II promoter in vivo. $E M B O$ J. 7: 2757-2763.

Wildeman, A.G., P. Sassone-Corsi, T. Grundström, M. Zenke, and P. Chambon. 1984. Stimulation of in vitro transcription from the SV40 early promoter by the enhancer involves a specific trans-acting factor. EMBO J. 3: 3129-3133.

Yamamoto, K.R. 1985. Steroid receptor regulated transcription of specific genes and gene networks. Annu. Rev. Genet. 19: 209-252.

Yamamoto, K.K., G.A. Gonzalez, W.H. Biggs III, and M.R. Montminy. 1988. Phosphorylation-induced binding and transcriptional efficacy of nuclear factor CREB. Nature 334: 494-498. 


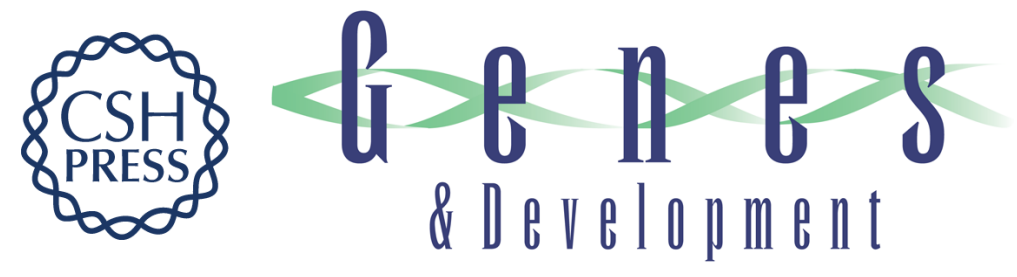

\section{In vivo monitoring of a cAMP-stimulated DNA-binding activity.}

F Weih, A F Stewart, M Boshart, et al.

Genes Dev. 1990, 4:

Access the most recent version at doi:10.1101/gad.4.8.1437

References This article cites 72 articles, 27 of which can be accessed free at: http://genesdev.cshlp.org/content/4/8/1437.full.html\#ref-list-1

License

Email Alerting Receive free email alerts when new articles cite this article - sign up in the box at the top Service right corner of the article or click here.

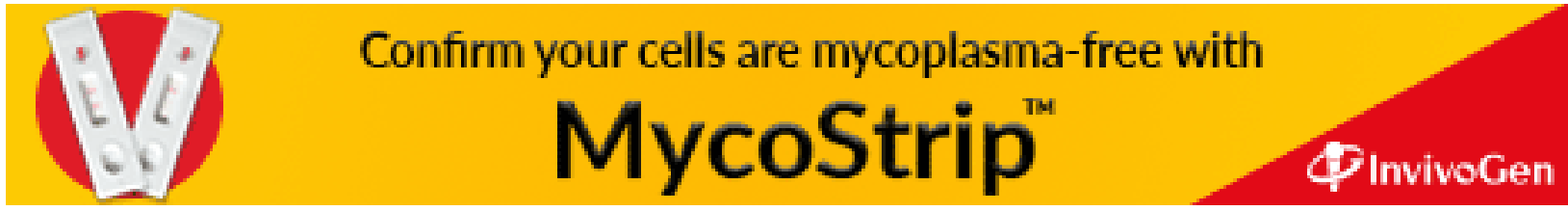

